Russian History 


\section{Russian History}

\section{Editor-in-Chief}

Lawrence N. Langer, University of Connecticut, USA

\section{Associate Editor}

Carol B. Stevens, Colgate University, USA

\section{Editorial Board}

Jeffrey P. Brooks, Johns Hopkins University, USA

Archie Brown, St. Antony's College, Oxford University, UK

Peter B. Brown, Rhode Island College, USA

Orlando Figes, Birbeck College, University of London, UK

Aleksandr Filiushkin, St. Petersburg State University, Russia

Simon Franklin, Clare College, University of Cambridge, UK

David Holloway, Stanford University, USA

Janet Martin, University of Miami, USA

Boris Mironov, St. Petersburg State University, Russia

Serhii Plokhii, Harvard University, USA

Peter Rutland, Wesleyan University, USA

Ronald Suny, University of Michigan, USA

Christine Worobec, Northern Illinois University, USA

Volumes published in this journal are listed at brill.com/ruhi 


\section{Russian History}

VOLUME 48 (2021)

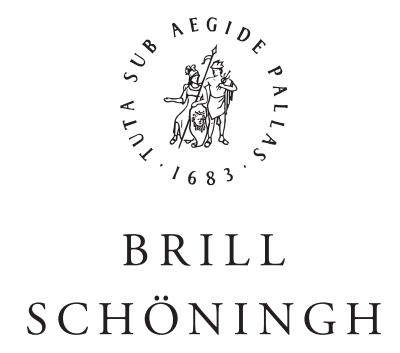


Brill Open Access options can be found at brill.com/openaccess.

Typeface for the Latin, Greek, and Cyrillic scripts: "Brill”. See and download: brill.com/brill-typeface.

ISSN $0094-288 \mathrm{X}$

E-ISSN 1876-3316

Copyright 2022 by Brill Schöningh, an Imprint of the Brill-Group (Koninklijke Brill NV, Leiden, The Netherlands; Brill USA Inc., Boston MA, USA; Brill Asia Pte Ltd, Singapore; Brill Deutschland GmbH, Paderborn, Germany).

Koninklijke Brill NV incorporates the imprints Brill, Brill Nijhoff, Brill Hotei, Brill Schöningh, Brill Fink, Brill mentis, Vandenhoeck \& Ruprecht, Böhlau Verlag and V\&R Unipress.

All rights reserved. No part of this publication may be reproduced, translated, stored in a retrieval system, or transmitted in any form or by any means, electronic, mechanical, photocopying, recording or otherwise, without prior written permission from the publisher. Requests for re-use and/or translations must be addressed to Koninklijke Brill NV via brill.com or copyright.com.

Brill has made all reasonable efforts to trace all rights holders to any copyrighted material used in this work. In cases where these efforts have not been successful the publisher welcomes communications from copyright holders, so that the appropriate acknowledgements can be made in future editions, and to settle other permission matters.

This journal is printed on acid-free paper and produced in a sustainable manner. 